\title{
FGF Receptor-Mediated Gene Delivery Using Ligands Coupled to PEI- $\beta$-CyD
}

\author{
Yiping Hu, ${ }^{1}$ Guping Tang, ${ }^{2}$ Jun Liu, ${ }^{2}$ Wenxiang Cheng, ${ }^{1}$ Ye Yue, ${ }^{1}$ Jinchao Li, ${ }^{1}$ and Peng Zhang1 \\ ${ }^{1}$ Center for Translational Medicine Research and Development, Shenzhen Institutes of Advanced Technology, \\ Chinese Academy of Science, Shen Zhen, Guangdong 518055, China \\ ${ }^{2}$ Institute of Chemical Biology and Pharmaceutical Chemistry, Zhejiang University, Hangzhou 310028, China
}

Correspondence should be addressed to Peng Zhang, superzhangpeng@163.com

Received 20 December 2011; Revised 9 February 2012; Accepted 14 February 2012

Academic Editor: Sabah Mohammed

Copyright (C) 2012 Yiping Hu et al. This is an open access article distributed under the Creative Commons Attribution License, which permits unrestricted use, distribution, and reproduction in any medium, provided the original work is properly cited.

\begin{abstract}
A novel vector with high gene delivery efficiency and special cell-targeting ability was developed using a good strategy that utilized low-molecular-weight polyethylenimine (PEI; molecular weight: $600 \mathrm{KDa}$ [PEI600]) crosslinked to $\beta$-cyclodextrin $(\beta$ $\mathrm{CyD}$ ) via a facile synthetic route. Fibroblast growth factor receptors (FGFRs) are highly expressed in a variety of human cancer cells and are potential targets for cancer therapy. In this paper, CY11 peptides, which have been proven to combine especially with FGFRs on cell membranes were coupled to PEI- $\beta$-CyD using $N$-succinimidyl-3-(2-pyridyldithio) propionate as a linker. The ratios of PEI600, $\beta$-CyD, and peptide were calculated based on proton integral values obtained from the ${ }^{1} \mathrm{H}-\mathrm{NMR}$ spectra of the resulting products. Electron microscope observations showed that CY11-PEI- $\beta$-CyD can efficiently condense plasmid DNA (pDNA) into nanoparticles of about $200 \mathrm{~nm}$, and MTT assays suggested the decreased toxicity of the polymer. Experiments on gene delivery efficiency in vitro showed that CY11-PEI- $\beta$-CyD/pDNA polyplexes had significantly greater transgene activities than PEI- $\beta$-CyD/pDNA in the COS-7 and HepG2 cells, which positively expressed FGFR, whereas no such effect was observed in the PC-3 cells, which negatively expressed FGFR. Our current research indicated that the synthesized nonviral vector shows improved gene delivery efficiency and targeting specificity in FGFR-positive cells.
\end{abstract}

\section{Introduction}

Numerous vectors have been explored for use in gene delivery. An ideal vector system efficiently uptakes and delivers drugs to target cells without stimulating significant immune responses, inflammation reactions, or cytotoxicity [1]. Although viruses are known to facilitate the entry of pDNA into cells, great concern about the safety and immunogenicity of viral vectors has made nonviral vectors a more attractive option than viral ones. Thus, there is a growing need to develop biocompatible polymeric gene carriers that will not elicit immune responses and toxic side effects $[2,3]$.

Among the nonviral vectors available, polyethylenimine (PEI) has shown high gene delivery efficiency both in vitro and in vivo [4]; as such, it has received significant attention as a research subject. PEI molecules consist of repeated basic units with a backbone of two carbons followed by one nitrogen atom and contain primary, secondary, and, in the case of branched PEIs, tertiary amino groups, each of which has the potential to be protonated $[5,6]$. Positively charged amino groups may interact with negatively charged phosphate groups of DNA molecules to form polymer-DNA polyplexes with sizes in the nanometer range that can be internalized by cells [7]. $\beta$-CyD-modified polymers have been shown to be able to stabilize cationic polymer/DNA complexes under physiological conditions, increase water solubility, show minimal cytotoxicity, and demonstrate good transfection efficiencies in many cell lines [8]. In improving the gene transfection efficiency of nonviral carriers, new strategies have been put forward to enhance the cellular uptake of PEI-based polyplexes; modification of the polymer must be done [9], such that specific ligands can be incorporated into the gene carriers. Several targeting moieties, including folic acid, transferrin, RGD peptide, HER 
peptide, EGF, and sugar moieties, have been employed in polymeric gene carriers to enhance target cell specificity and transfection efficiency.

Among these strategies, the ligand linkage strategy appears to be the most attractive [7]. Receptor-meditated gene delivery enhances the targeting ability and gene delivery efficiency of PEI- $\beta$-CyD/pDNA polyplexes. However, when ligands, especially those with high molecular weights, are conjugated with PEI, the gene delivery efficiency of the polyplexes may be affected by a lower DNA condensation, larger particle size, and increased spatial steric hindrance $[10$, 11]. Many functional peptides that specifically target tumors were recently identified and applied as substitutes of whole molecular ligands for the construction of targeting vectors to overcome some disadvantages of nonviral polyplexes. In the present study, a CY11 peptide-mediated nanopolymer was prepared, its physicochemical properties were characterized, and its transfection activities in FGF receptors (FGFRs) overexpressing and under expressing cells were determined [12]. The results indicated that FGFR-targeted polyplexes had high gene efficiency and low cytotoxicity.

\section{Materials and Methods}

2.1. Chemicals and Reagents. PEI (branched $600 \mathrm{KDa}$ or PEI $25 \mathrm{KDa}), \quad N$-succinimidyl-3-(2-pyridyldithio) propionate $($ SPDP, Molecular weight = 312.4 Da), 1-(4, 5-dimethylthiazol-2-yl)-3,5-diphenylformazan (MTT), dimethyl sulfoxide (DMSO), and triethylamine (TEA) were obtained from Sigma-Aldrich. The oligopeptide (CY11: CGMQLPLATWY) was synthesized by GL Biochem (Shanghai, China), and its amino acid sequence was confirmed using mass spectrography. 1,1-Carbonyldiimidazole (CDI) was obtained from Pierce (Rockford, IL, USA). Plasmid pCAG-Luc-encoding luciferase activity assay kits were obtained from Promega (Madison, WI, USA). The plasmid pEGFP encoding green fluorescence protein (GFP) was provided by the Institute of Immunology, Zhe Jiang university, Hangzhou, China.

COS-7 (FGFR positive; a continuous cell line derived from an African green monkey kidney), HepG2 (FGFR positive; a human hepatocellular cancer cell line), and PC-3 (FGFR negative; a human prostate adenocarcinoma cell line) were obtained from the American Type Culture Collection (ATCC, Rockville, MD, USA). These cell lines were maintained in RPMI1640 supplemented with 10\% fetal calf serum (FCS), $2 \mathrm{mM}$ glutamine, 100 units $/ \mathrm{mL}$ penicillin, and $100 \mu \mathrm{g} / \mathrm{mL}$ streptomycin in a $37^{\circ} \mathrm{C}$ incubator with $5 \%$ $\mathrm{CO}_{2}$.

2.2. Synthesis of PEI- $\beta-C y D$ and CY11-PEI- $\beta-C y D$. PEI- $\beta$ $\mathrm{CyD}$ was prepared according to the method of Tang et al. [13].

SPDP $(3.6 \mathrm{mg}, 0.01 \mathrm{mmol})$ was dissolved in DMSO $(0.3 \mathrm{~mL})$, and PEI- $\beta$-CyD (120 mg, $0.65 \mathrm{mmol}$ ) was dissolved in DMSO $(3 \mathrm{~mL})$. The activation reaction proceeded under a nitrogen atmosphere in the dark for $1 \mathrm{~h}$ at room temperature. Peptide $(12 \mathrm{mg}, 12.3 \mu \mathrm{mol}$ ) was dissolved in $1 \times$ PBS buffer $(1 \mathrm{~mL})$. The peptide solution was dropped slowly into the SPDP-activated PEI- $\beta$-CyD solution under stirring at room temperature under nitrogen for $3 \mathrm{~h}$. The product was dialyzed against pure running water with a dialysis membrane (molecular weight cutoff $=(8,000-14,000)$ ) and lyophilized for $48 \mathrm{~h}$. The final product was stored at $-80^{\circ} \mathrm{C}$.

2.3. ${ }^{1}$ H-Nuclear Magnetic Resonance $\left({ }^{1} H\right.$-NMR) Analysis. The structures of CY11, PEI- $\beta$-CyD, and CY11-PEI- $\beta$-CyD were ascertained by studying their ${ }^{1} \mathrm{H}-\mathrm{NMR}$ spectra. Samples ( $5 \mathrm{mg}$ ) were dissolved in $0.7 \mathrm{~mL}$ deuterium oxide $\left(\mathrm{D}_{2} \mathrm{O}\right)$. The spectra were recorded using a Bruker $400 \mathrm{MHz}$ NMR spectrometer with 32 scans at room temperature.

2.4. Agarose Gel Electrophoresis Assay. The electrophoretic mobility of the polymer/pDNA polyplexes was measured using a gel electrophoresis system. An appropriate amount of polymer was added to an equal volume of pDNA solution to achieve the desired polymer/pDNA ratio. Gel electrophoresis was conducted at room temperature in TEA buffer with $1 \%$ $(\mathrm{w} / \mathrm{w})$ agarose gel at $100 \mathrm{~V}$ for $45 \mathrm{~min}$. DNA bands were visualized by an UV illuminator.

2.5. Electron Microscope Detection. Polyplexes of CY11-PEI$\beta-\mathrm{CyD} / \mathrm{pDNA}$ at a $\mathrm{N} / \mathrm{P}$ ratio of 25 were prepared in $0.9 \%$ saline. After vortexing for $1 \mathrm{~min}$ and standing for $30 \mathrm{~min}$, the polyplexes were observed under a transmission electron microscope (JEOL, JEM-2010 TEM, JPN).

2.6. Cell Viability Assay. COS-7, HepG2, and PC-3 cells were grown in RPMI1640 supplemented with 10\% FCS at $37^{\circ} \mathrm{C}$ and $5 \% \mathrm{CO}_{2}$ in 96-well plates (Falcon; Becton Dickinson, USA) at an initial density of 8,000 cells/well to 10,000 cells/well. The growth medium was replaced with $200 \mu \mathrm{L}$ serum-free RPMI1640 containing PEI $25 \mathrm{KDa}$, PEI600, PEI- $\beta$-CyD, and CY11-PEI- $\beta$-CyD at different concentrations $(5,10,20,40,80,120$, and $160 \mathrm{nmol} / \mathrm{mL})$. After $4 \mathrm{~h}$ of incubation, the medium was replaced with $200 \mu \mathrm{L}$ freshly grown medium; following another $24 \mathrm{~h}$ of incubation, the cells were washed once with PBS. Then $90 \mu \mathrm{L}$ fresh medium and $10 \mu \mathrm{L}$ MTT solution $(5 \mathrm{mg} / \mathrm{mL})$ were added to each well. The plates were vigorously shaken before measurement. Cell viability was assessed by obtaining the absorbance of the products at $570 \mathrm{~nm}$ as measured by a BioRad microplate reader (Model 550, BioRad). Cell growth $(\%)$ relative to the control cells cultured in the media without PEI25KDa, PEI600, PEI- $\beta$-CyD, or CY11PEI- $\beta$-CyD was calculated using the following formula: $[A]_{\text {test }} /[A]_{\text {control }} \times 100$.

2.7. In Vitro Gene Delivery. COS-7, HepG2, and PC-3 cells were used for gene delivery tests. The cells were seeded in 24 -well plates at a density of $1.0 \times 10^{5} /$ well with $0.6 \mathrm{~mL}$ RPMI1640 containing 10\% FCS. After $24 \mathrm{~h}$ of incubation, the culture media were replaced with $0.6 \mathrm{~mL}$ serumfree RPMI1640. Polyplexes of PEI600/PCAG-luc, PEI- $\beta$ CyD/PCAG-luc, and CY11-PEI- $\beta$-CyD/PCAG-luc with different $\mathrm{N} / \mathrm{P}$ ratios $(20,25,30,35,40)$ containing $1 \mu \mathrm{g}$ PCAG-luc were added to each well, where as polyplexes of 


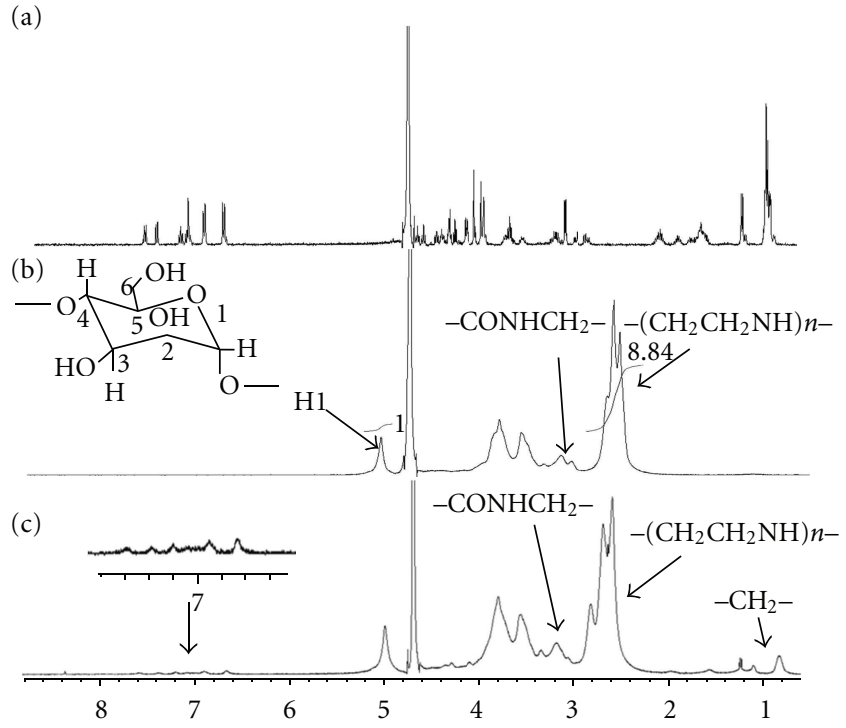

Figure 1: ${ }^{1} \mathrm{H}-\mathrm{NMR}$ analysis of (a) CY11, (b) PEI- $\beta$-CyD, and (c) CY11-PEI- $\beta$-CyD. The peaks at $2.5-3.2 \mathrm{ppm}$ are assigned to the protons of PEI600 in (b) and (c). At 0.8-1.3 and 6.7-7.6 ppm, the new peaks are assigned to the protons of the amino acids of CY11 in (a) and (c).

PEI25KDa/PCAG-luc at an N/P ratio of 10 were included in the control group. After a $4 \mathrm{~h}$ of incubation, the medium was removed and supplemented with fresh medium containing 10\% FBS. Luciferase gene expression was determined $36 \mathrm{~h}$ after transfection using a commercial luciferase assay kit (Promega, USA). The transfection efficiency was expressed as relative light units per milligram of cell protein, the concentration of which was determined using a protein assay kit (BCA, Pierce, USA).

pEGFP plasmids were used to detect the green fluorescence emitted by green fluorescence proteins after the plasmids were delivered to the COS-7, HepG2, and PC-3 cells at an N/P ratio of 25 .

2.8. Statistical Analysis. Unless otherwise noted, the results from in vitro experiments represent at least two independent experiments. All results were expressed as means \pm standard error of mean (SEM). Statistical analysis was performed using one-way analysis of variance (ANOVA) and the LSD test. Analysis was conducted using SPSS12.0.A mean with $P<0.05$ considered statistically significant.

\section{Results}

3.1. Synthesis and Characterization of CY11-PEI- $\beta-C y D$. CY11-PEI- $\beta$-CyD synthesis was conducted according to Tang et al. [13]. The ${ }^{1} \mathrm{H}-\mathrm{NMR}$ spectra of PEI- $\beta-\mathrm{CyD}$ were obtained to determine the ratio of PEI600 and $\beta$ CyD (Figure 1(b)). The stoichiometry between PEI600 and $\beta$-CyD was calculated using the characteristic peaks of PEI600 ( $\left.-\mathrm{CH}_{2} \mathrm{CH}_{2} \mathrm{NH}-\right)$ and the $\mathrm{C}-1$ hydrogen in $\beta$-CyD. In our experiment, the molar ratio of PEI600 and $\beta$-CyD was approximately $1: 1.2$.
The CY11 with a single cysteine at the end was directly coupled onto the SPDP-activated PEI- $\beta$-CyD to produce the CY11-PEI- $\beta$-CyD. The successful synthesis of CY11-PEI- $\beta$ CyD was confirmed using ${ }^{1} \mathrm{H}-\mathrm{NMR}$ spectra, as shown in Figure 1(c). The characteristic peaks of PEI $\left(-\mathrm{NHCH}_{2} \mathrm{CH}_{2}-\right)$ appeared at $\delta 2.5 \mathrm{ppm}$ to $3.3 \mathrm{ppm}$, those of $\beta$-CyD appeared at $\delta 5.0 \mathrm{ppm}$ and $\delta 3.4 \mathrm{ppm}$ to $4.0 \mathrm{ppm}$, and those of the CY11 peptide appeared at $\delta 0.8 \mathrm{ppm}$ to $1.3 \mathrm{ppm}$ and $6.7 \mathrm{ppm}$ to $7.6 \mathrm{ppm}\left(-\mathrm{CH}_{2}-\right.$ protons of peptide $)$ of CY11-PEI- $\beta$-CyD. These findings suggest the successful conjugation of CY11 to PEI- $\beta$-CyD.

3.2. Complex Formation of CY11-PEI- $\beta-C y D / D N A$. The binding capability of PEI- $\beta$-CyD and CY11-PEI- $\beta-C y D$ to DNA was evaluated using agarose gel electrophoresis (Figure 2), and CY11-PEI- $\beta$-CyD was found to stably form an N/P ratio of 4 (Figure $2(\mathrm{~b})$ ). However, the ability to binding DNA was delayed, which was likely caused by the steric hindrance of the conjugated peptides. Comparison of PEI- $\beta-\mathrm{CyD}$ with condensed DNA at an N/P ratio of 3 (Figure 2(a)) showed that the peptide converted the PEI primary amine into an amide, but the efficiency of modification was very low $(<5 \%$ of the primary amines modified).

The particle size of the copolymer/DNA complexes is an important factor that affects transfection activity. The morphology of the CY11-PEI- $\beta$-CyD/DNA complex was observed under TEM (Figure 3). The particle size of the complexes at an N/P ratio of 25/1 was approximately $200 \mathrm{~nm}$, which was a suitable diameter for gene delivery.

3.3. Toxicity Assay of Copolymer. MTT assays of the COS7, HepG2, and PC-3 cells were performed to evaluate the cytotoxicity of PEI600, PEI- $\beta$-CyD, CY11-PEI- $\beta$-CyD, and PEI25KDa over an incubation period of $4 \mathrm{~h}$ at concentrations ranging from 0 to $160 \mathrm{nmol} / \mathrm{mL}$, as shown in Figure 4 . In the present study, CY11-PEI- $\beta$-CyD showed low toxicity against the COS-7, HepG2, and PC-3 cell lines compared with the control group (PEI25KDa). When the concentration was over $120 \mathrm{nmol} / \mathrm{mL}$, the percentage of cell viability remained above $60 \%$. A very sharp drop in the number of viable cells was observed for PEI25KDa with increasing the concentration. Furthermore, the modification of PEI with $\beta$ CyD led to a reduction in toxic side effects in vitro.

3.4. Gene Transfer In Vitro. In verifying the enhanced gene delivery ability of CY11-PEI- $\beta$-CyD and the targeting ability of the CY11 motif, gene delivery experiments in vitro were conducted in COS-7 (FGFR-positive), HepG2 (FGFRpositive), and PC-3 (FGFR-negative) cells using plasmid pCAG-Luc. The transfection efficiency of the CY11-PEI$\beta$-CyD/DNA complex in the COS-7 cells is shown in Figure 5(a). The data demonstrated that the transfection efficiency of CY11-PEI- $\beta$-CyD was twofold higher than that of PEI- $\beta-\mathrm{CyD}$ at an $\mathrm{N} / \mathrm{P}$ ratio of 25 achieved at $4.13 \times 10^{10} \mathrm{RLU} / \mathrm{mg}$ protein. Similarly, an improvement in transfection efficiency was observed with CY11-PEI- $\beta$ CyD in HepG2 cells (Figure 5(b)). By contrast, in PC3 cells 


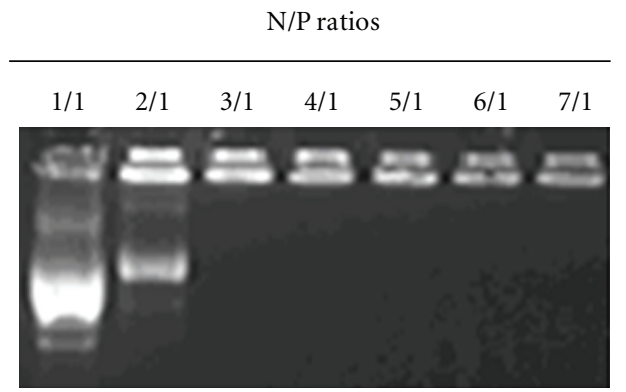

(a)

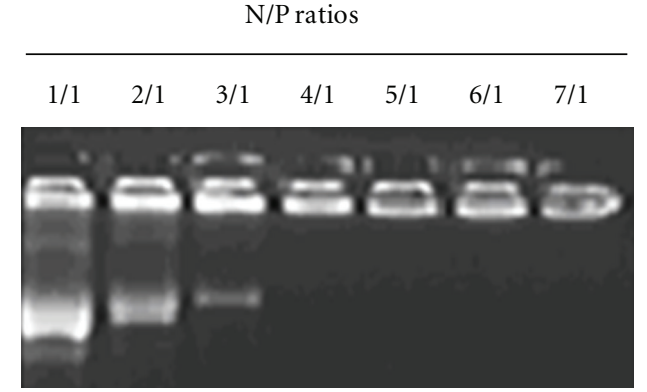

(b)

FIGURE 2: Agarose gel electrophoresis of $0.5 \mu \mathrm{g}$ DNA complexed with (a) PEI- $\beta$-CyD and (b) CY11-PEI- $\beta$-CyD at N/P ratios from 1 to 7.

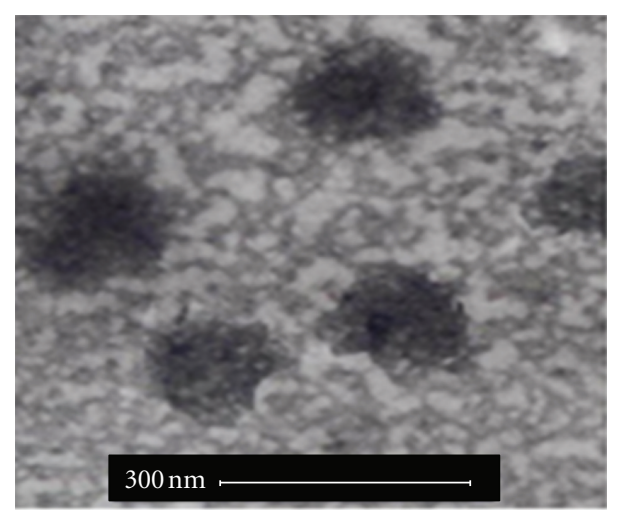

Figure 3: Transmission electron micrograph of the CY11-PEI- $\beta$ CyD/DNA polyplex. The polyplex is spherical with a diameter of about $200 \mathrm{~nm}$.

(Figure 5(c)) and at an N/P ratio of 20, the efficiency of PEI$\beta$-CyD was about one and a half-fold higher than that of CY11-PEI- $\beta$-CyD. Even at other N/P ratios, including 25,30 , 35 , and 40 , the efficiency of PEI- $\beta$-CyD was higher than that of CY11-PEI- $\beta$-CyD. "Gold standard" branched PEI25KDa exhibited the highest gene expression at N/P ratio of 10 and decreased with higher N/P [13]. PEI- $\beta$-CyD and CY11-PEI$\beta$-CyD complexes showed higher transfection efficiency at $\mathrm{N} / \mathrm{P}$ ratios of 20, 25, and 30 than PEI25KDa complex at its optimal N/P of 10.

In order to further study the gene delivery capability of CY11-PEI- $\beta$-CyD, pEGFP plasmids were transferred to the COS-7, HepG2, and PC-3 cells to enable the direct observation of green fluorescence under a fluorescence microscope (Figures 5(d), 5(e) and 5(f)). The transfer efficiency was far higher in COS-7 and HepG2 cells than in PC-3 cells. In summary, the transfection study demonstrated that CY-11 peptide-mediated PEI- $\beta$-CyD vectors could offer a strategy for targeted gene delivery, especially for FGFR highly expressing tumor cells.

\section{Discussion}

The gene delivery ability of PEI was first discovered by Boussif et al. in 1995 [14]. Since then, the mechanism has been extensively explored, and many strategies have been undertaken in attempts to improve its efficiency of PEI. PEI is widely used as a nonviral gene transfer vector. In the field of biomedical science, PEI could be an effective gene delivery vector for in vitro and in vivo transfection. However, like other general nonviral vectors [15], PEI shows low gene delivery efficiency and high cytotoxicity compared with viral vectors. One of the strategies that may be used to improve the efficiency of PEI is to modify PEI with ligands that target specific receptors on cell membranes [16]. Many peptides function as ligands for targeted nonviral gene delivery systems to specific cell and/or tissue types within the body and enhance the delivery of nonviral vectors. EGF, folate, Her-2, transferring, and antibodies are commonly used as such ligands, but obtaining, identifying, and isolating these ligands are complicated and tedious [12]. More importantly, the combination of ligands, especially those with high molecular weights, may potentially affect the biological behavior of the vector and decrease gene delivery efficiency due to steric affects [7].

FGFRs are highly expressed in many tumor cells and are upregulated in proliferating endothelial cells during angiogenesis [17]. They can improve gene delivery by overcoming identified cellular barriers and targets for cancer gene therapy. Maruta et al. [12] found that the oligopeptide CY11 binds to FGFR receptors with high affinity via a novel phage display technology and verified the occurrence of enhanced gene expression using polylysine-based complexes with the oligopeptides.

In the present study, the oligopeptide CY11 was selected to conjugate with PEI- $\beta$-CyD, and the chemical and biological characteristics of the resulting CY11-PEI- $\beta-\mathrm{CyD} / \mathrm{pDNA}$ polyplexes were investigated. PEI- $\beta$-CyD has an abundance of amine groups, much higher than the number of sulfhydryl groups in CY11, such that the complete conjugation of CY11 with PEI- $\beta$-CyD is possible. The molar ratio of CY11 to PEI- $\beta$-CyD in the CY11-PEI- $\beta$-CyD complex equaled that found in theoretical calculations from ${ }^{1} \mathrm{H}-\mathrm{NMR}$ results.

DNA condensation, particle size, and toxicity of the polyplexes are closely related to delivery efficiency [18]. Ideally, polyplexes should be homogeneous, soluble, stable, small, 


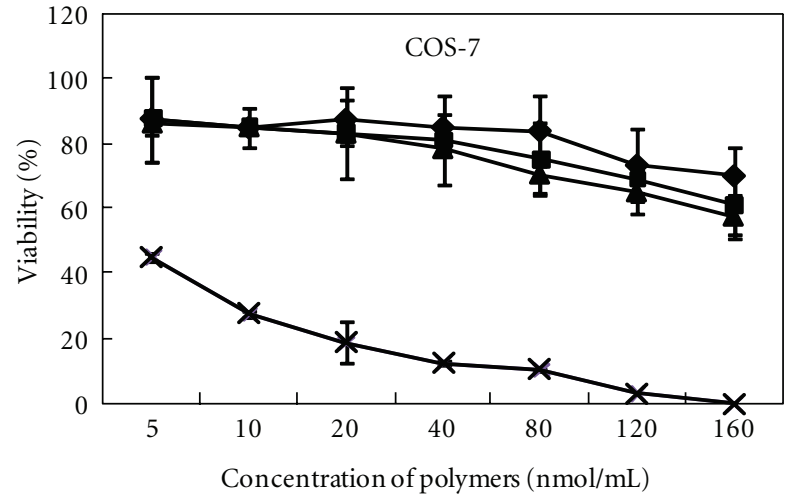

(a)

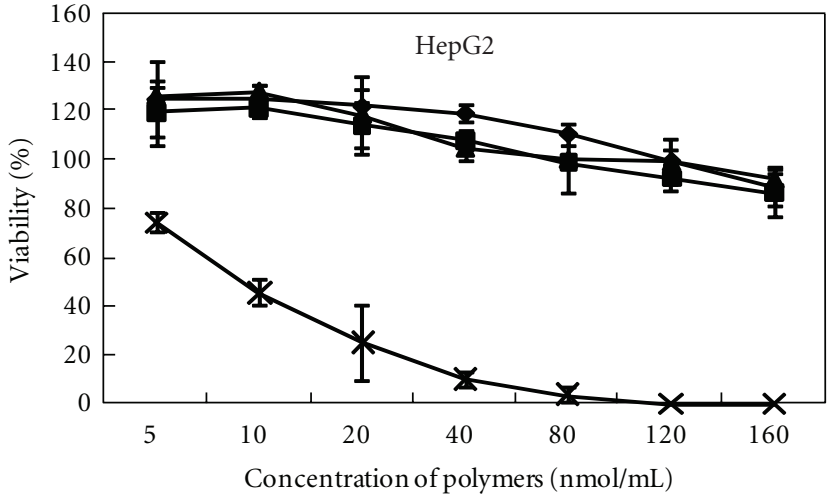

(b)

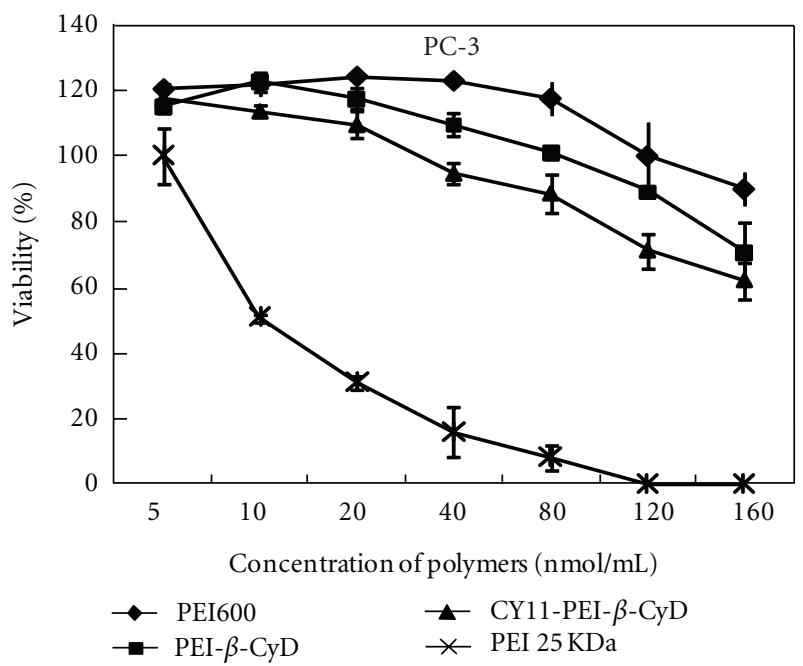

(c)

FIgure 4: The cytotoxicity of PEI600, PEI- $\beta$-CyD, CY11-PEI- $\beta$-CyD, and PEI25KDa against (a) COS-7, (b) HepG2, and (c) PC-3 cells. The cells were treated with polymer of different concentrations for $4 \mathrm{~h}$ in a serum-containing medium. Cell viability was determined using MTT assays and expressed as percentages of the control. When the concentration of the polymer was $<20 \mathrm{nmol} / \mathrm{mL}$, the toxicities of the polymers were similar $(P>0.05)$.

and have low toxicity. Gel retardation assay results showed that, after conjugation of CY11, the ability of PEI- $\beta$-CyD for pDNA condensation decreased, signifying that the surface charges of PEI- $\beta$-CyD were blocked by CY11. The cells toxicity assay confirmed this result and showed that, even at a CY11-PEI- $\beta$-CyD concentration of $120 \mathrm{nmol} / \mathrm{mL}$, the percentage of cell viability remained above $60 \%$. The cytotoxicity of PEI was related to the positively charged amine groups, so PEI25KDa was found to have high toxicity. CY11 itself did not stimulate the growth of cells. Spherical polyplexes of about $200 \mathrm{~nm}$ in diameter were found to be suitable for gene delivery.

In examining the role of CY11 oligopeptides, FGFRs were highly expressed on COS-7 and HepG2 cells and lowly expressed on PC-3 cell surfaces. The efficiency of CY11PEI- $\beta$-CyD $(25: 1)$ in COS-7 $(25: 1)$ and HepG2 cells was about twofold higher than that of the PEI- $\beta$-CyD group and higher than that of PEI25KDa $(10: 1)$ at a suitable N/P ratio. Based on the in vitro results obtained from COS-7 cells, although not very obvious, the efficiency of CY11-PEI$\beta$-CyD $(25: 1)$ was found to be higher than that of CY11PEI- $\beta$-CyD polymers with other conjugation ratios, such as $20: 1,30: 1,35: 1$, and $40: 1$. An optimal conjugation ratio of oligopeptides is thus suggested to be present in this type of molecules. Toolow or toohigh conjugation ratios of CY11 may affect the efficiency observed because of insufficient ligand-mediated actions or steric hindrance effects. The decreased efficiency of CY11-PEI- $\beta$-CyD in PC-3 cells indicated that FGFR mediated the enhanced transgene activity of CY11-PEI- $\beta$-CyD. The pathway of polyplex binding to cells is a receptor-mediated process and not a simple static electricity one; thus, an enhancement in efficiency could be expected [12]. By contrast, for receptor-negative cells, conjugation of the corresponding ligands yielded no benefits for achieving efficiency. Considering the high expression of FGFR in most tumor cells, the observed enhancement in efficiency indicated that CY11-PEI- $\beta$-CyD could be used in future applications as a delivery vector for cancer gene therapy. 


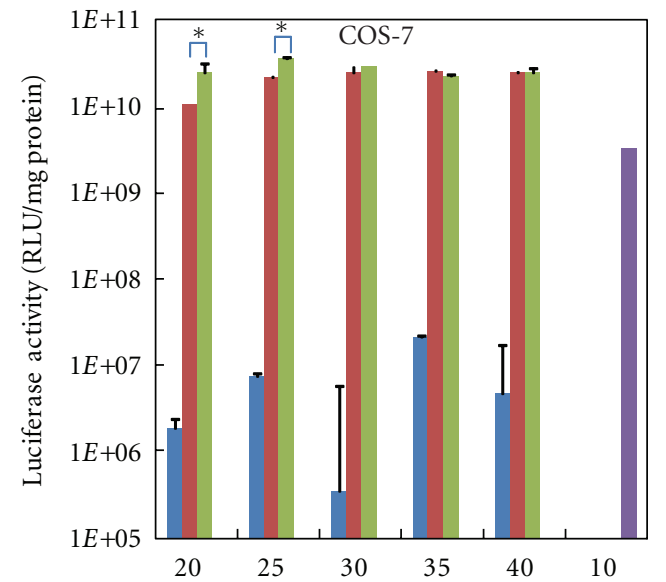

(a)

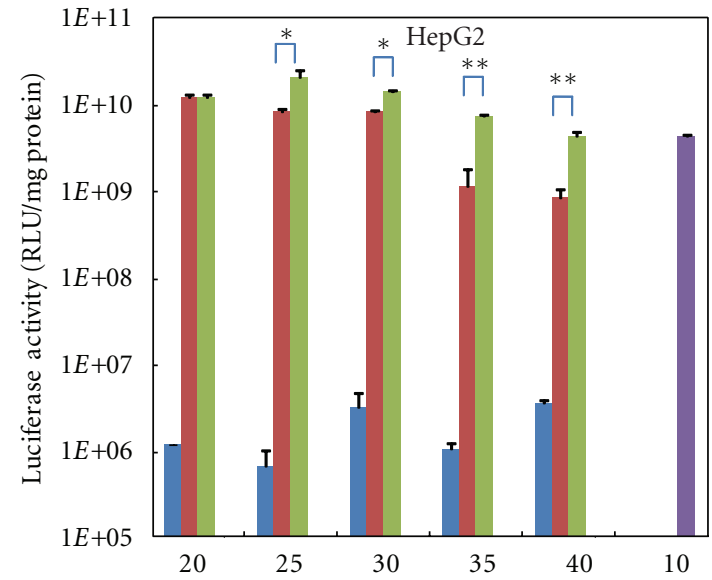

(b)

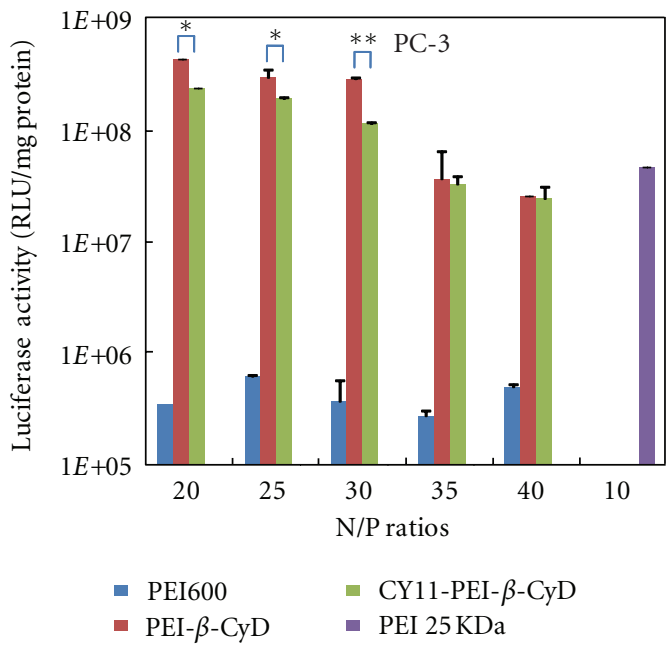

(c)

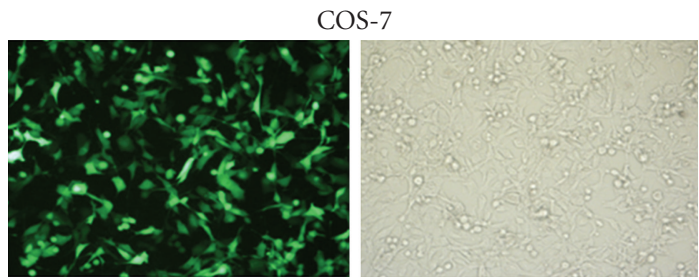

(d)

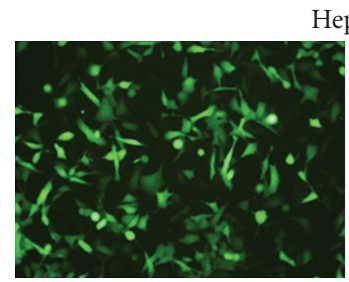

(e)

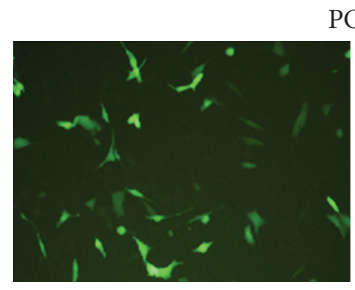

PC-3

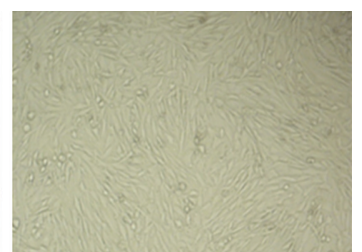

(f)

Figure 5: The gene delivery efficiencies of PEI600, PEI- $\beta$-CyD, CY11-PEI- $\beta$-CyD, and PEI25KDa with different N/P ratios in (a) COS-7, (b) HepG2, and (c) PC-3 cells. PEI25KDa at an N/P ratio of 10 shows the highest gene delivery efficiency. Data were shown as mean \pm SD, $\left({ }^{*} P<0.05\right.$ as compared with other samples in the same group). The green fluorescence emitted by green proteins expressed after the transfer of CY11-PEI- $\beta$-CyD/pEGFP at an N/P ratio of 25 to cells: (d) COS-7, (e) HepG2, and (f) PC-3 cells. A fluorescence microscope is used. Fluorescence is more evident in COS-7 (FGFR-positive) and HepG2 (FGFR-positive) cells than in PC-3 (FGFR-negative) ones. 
In summary, the successfully synthesized CY11-PEI- $\beta$ CyD polymer can efficiently condense DNA plasmids into spherical particles of about $200 \mathrm{~nm}$ in diameter and with positive zeta potential. The polymer has less cytotoxicity and more efficient gene delivery capabilities than PEI- $\beta$-CyD in vitro. It also has FGFR-targeting ability.

\section{Conflict of Interests}

The authors declare that there is no conflict of interests in this paper.

\section{References}

[1] D. Li, H. Yu, H. Huang et al., "FGF receptor-mediated gene delivery using ligands coupled to polyethylenimine," Journal of Biomaterials Applications, vol. 22, no. 2, pp. 163-180, 2007.

[2] D. W. Pack, A. S. Hoffman, S. Pun, and P. S. Stayton, "Design and development of polymers for gene delivery," Nature Reviews Drug Discovery, vol. 4, no. 7, pp. 581-593, 2005.

[3] M. Lee and S. W. Kim, "Polyethylene glycol-conjugated copolymers for plasmid DNA delivery," Pharmaceutical Research, vol. 22, no. 1, pp. 1-10, 2005.

[4] R. Goyal, S. K. Tripathi, S. Tyagi et al., "Gellan gum blended PEI nanocomposites as gene delivery agents: evidences from in vitro and in vivo studies," European Journal of Pharmaceutics and Biopharmaceutics, vol. 79, no. 1, pp. 3-14, 2011.

[5] A. Swami, R. K. Kurupati, A. Pathak, Y. Singh, P. Kumar, and K. C. Gupta, "A unique and highly efficient nonviral DNA/siRNA delivery system based on PEI-bisepoxide nanoparticles," Biochemical and Biophysical Research Communications, vol. 362, no. 4, pp. 835-841, 2007.

[6] K. C. R. Bahadur and H. Uludağ, "A comparative evaluation of disulfide-linked and hydrophobically-modified PEI for plasmid delivery," Journal of Biomaterials Science, Polymer Edition, vol. 22, no. 7, pp. 873-892, 2011.

[7] O. V. Chumakova, A. V. Liopo, V. G. Andreev et al., "Composition of PLGA and PEI/DNA nanoparticles improves ultrasound-mediated gene delivery in solid tumors in vivo," Cancer Letters, vol. 261, no. 2, pp. 215-225, 2008.

[8] K. Wada, H. Arima, T. Tsutsumi et al., "Improvement of gene delivery mediated by mannosylated dendrimer $/ \alpha$ cyclodextrin conjugates," Journal of Controlled Release, vol. 104, no. 2, pp. 397-413, 2005.

[9] B. Chertok, A. E. David, and V. C. Yang, "Polyethyleneiminemodified iron oxide nanoparticles for brain tumor drug delivery using magnetic targeting and intra-carotid administration," Biomaterials, vol. 31, no. 24, pp. 6317-6324, 2010.

[10] M. Neu, D. Fischer, and T. Kissel, "Recent advances in rational gene transfer vector design based on poly(ethylene imine) and its derivatives," Journal of Gene Medicine, vol. 7, no. 8, pp. 9921009, 2005.

[11] J. A. Fortune, T. I. Novobrantseva, and A. M. Klibanov, "Highly effective gene transfection in vivo by alkylated polyethylenimine," Journal of Drug Delivery, vol. 20, pp. 4058, 2011.

[12] F. Maruta, A. L. Parker, K. D. Fisher et al., "Identification of FGF receptor-binding peptides for cancer gene therapy," Cancer Gene Therapy, vol. 9, no. 6, pp. 543-552, 2002.

[13] G. P. Tang, H. Y. Guo, F. Alexis et al., "Low molecular weight polyethylenimines linked by $\beta$-cyclodextrin for gene transfer into the nervous system," Journal of Gene Medicine, vol. 8, no. 6, pp. 736-744, 2006.

[14] O. Boussif, F. LezoualC’H, M. A. Zanta et al., "A versatile vector for gene and oligonucleotide transfer into cells in culture and in vivo: polyethylenimine," Proceedings of the National Academy of Sciences of the United States of America, vol. 92, no. 16, pp. 7297-7301, 1995.

[15] G. Liu, J. Xie, F. Zhang et al., "N-Alkyl-PEI-functionalized iron oxide nanoclusters for efficient siRNA delivery," Small, vol. 7, no. 19, pp. 2742-2749, 2011.

[16] X. Bai, D. Miao, J. Li, D. Goltzman, and A. C. Karaplis, “Transgenic mice overexpressing human fibroblast growth factor 23 (R176Q) delineate a putative role for parathyroid hormone in renal phosphate wasting disorders," Endocrinology, vol. 145, no. 11, pp. 5269-5279, 2004.

[17] L. Cai, N. Qiu, X. Li et al., "A novel truncated basic fibroblast growth factor fragment-conjugated poly (ethylene glycol)cholesterol amphiphilic polymeric drug delivery system for targeting to the FGFR-overexpressing tumor cells," International Journal of Pharmaceutics, vol. 408, no. 1-2, pp. 173-182, 2011.

[18] B. Liang, M. L. He, Z. P. Xiao et al., "Synthesis and characterization of folate-PEG-grafted-hyperbranched-PEI for tumortargeted gene delivery," Biochemical and Biophysical Research Communications, vol. 367, no. 4, pp. 874-880, 2008. 

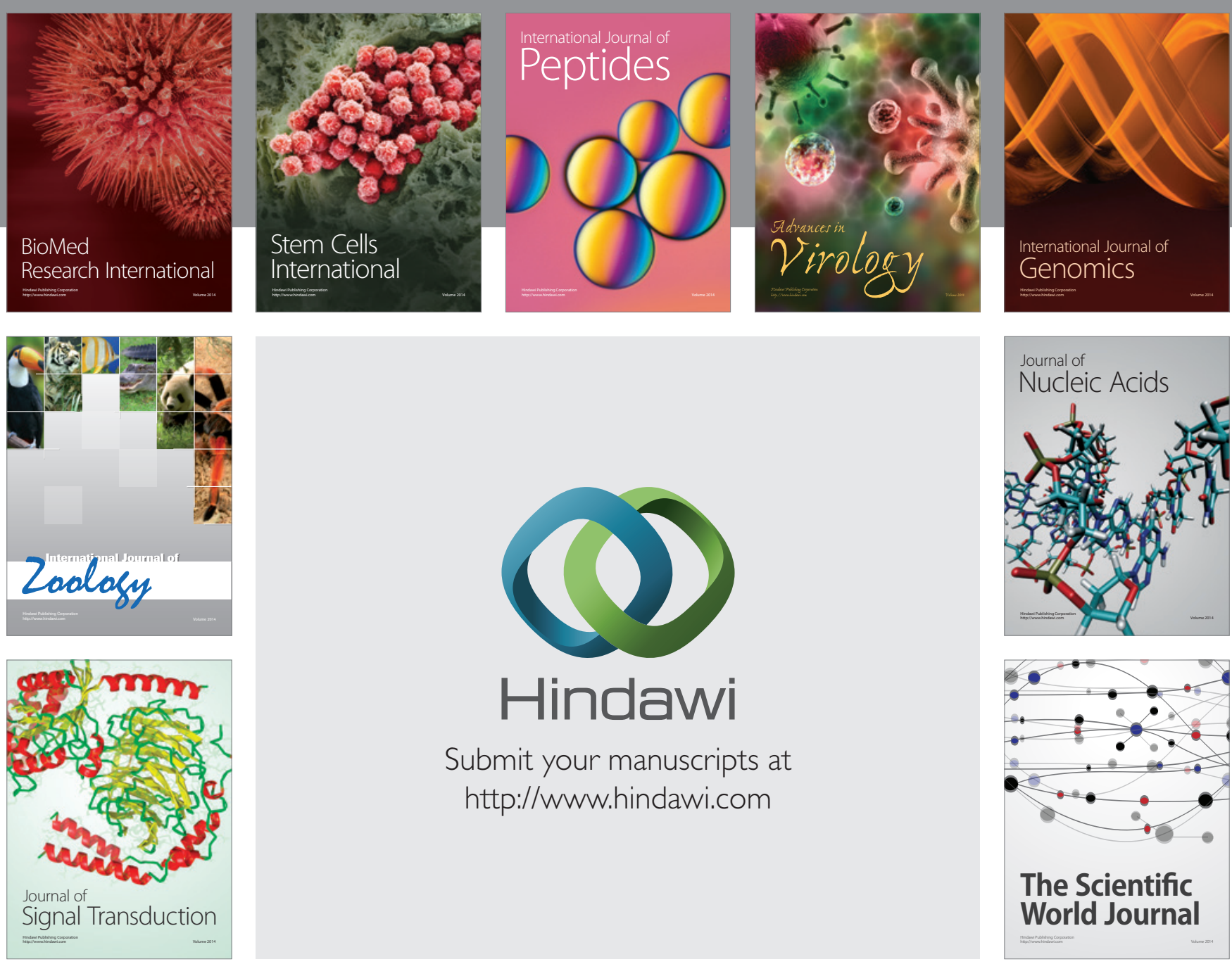

Submit your manuscripts at

http://www.hindawi.com
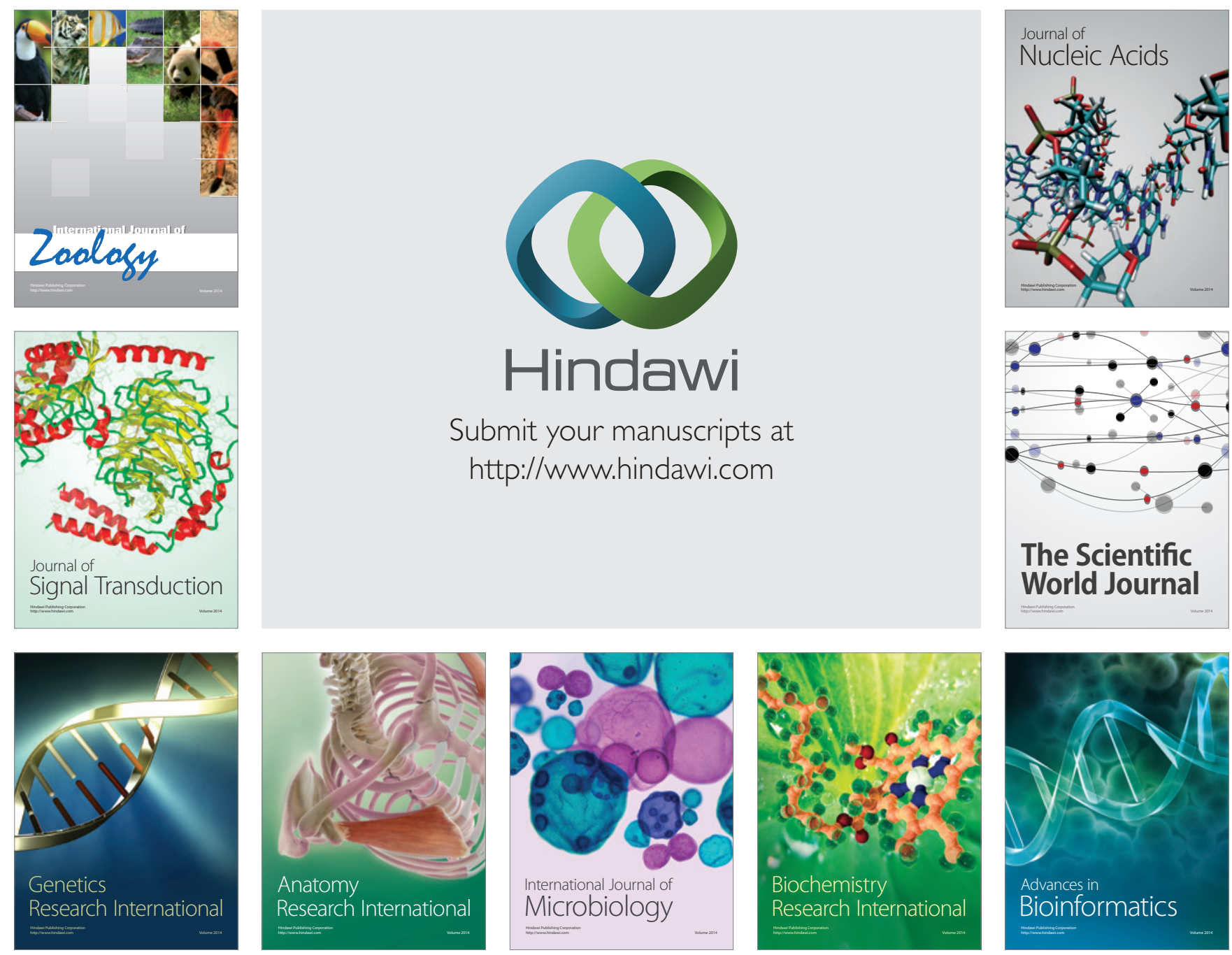

The Scientific World Journal
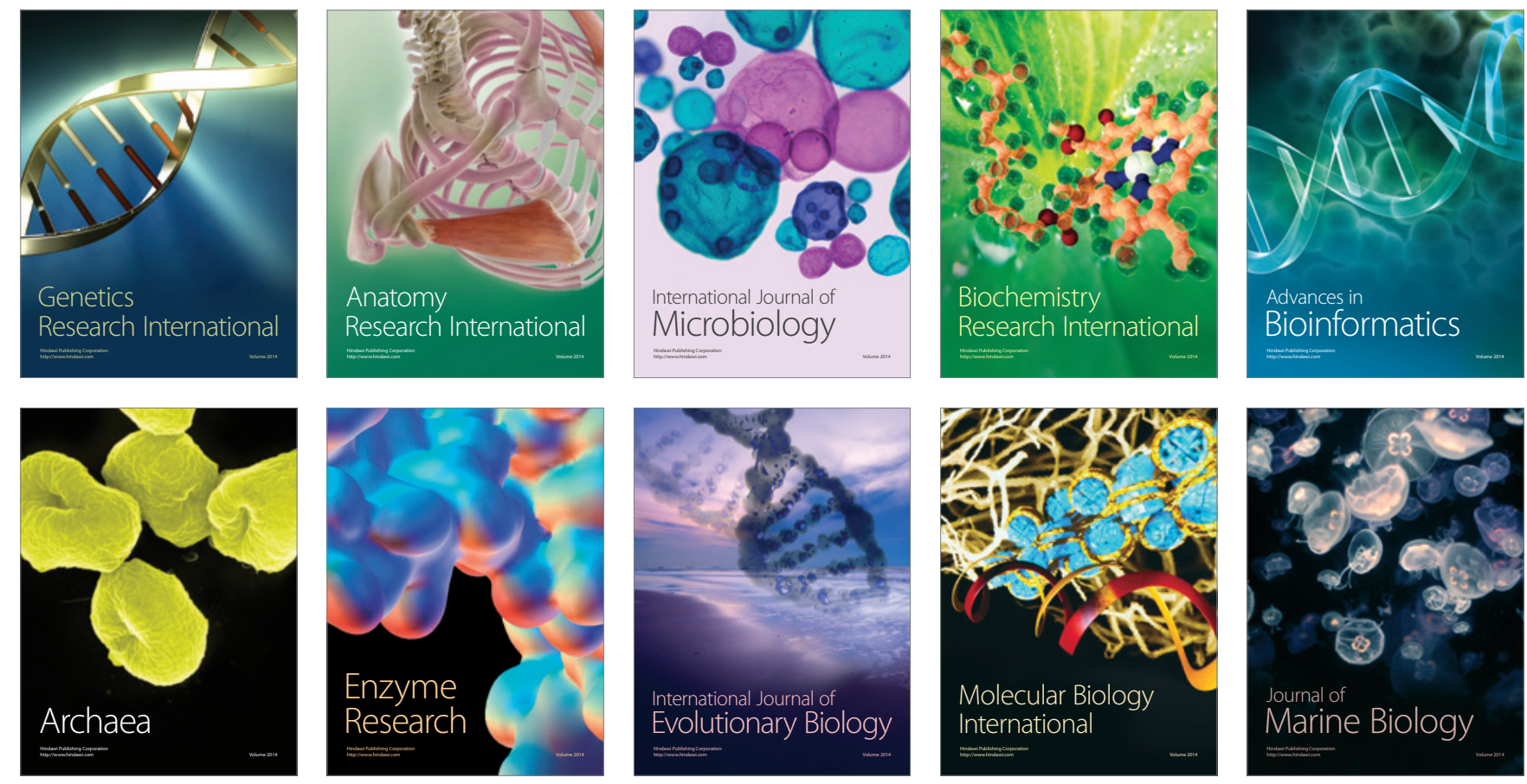